\title{
Effects of Pup Exposure to Maternal Nest Building in Virgin Female and Male Mice
}

\author{
Toru R. SAITO, Makoto KATSUYAMA and Kazuaki W. TAKAHASHI* \\ Toxicology Division, Institute of Environmental Toxicology, Suzuki-cho 2-772, \\ Kodaira-shi, Tokyo 187, Japan and *Laboratory of Laboratory \\ Animal Science, Nippon Veterinary \& Zootechnical College, \\ Kyonan-cho 1-7-1, Musashino-shi, Tokyo 180.
}

(Received for publication : May 22, 1981)

\begin{abstract}
Nest-building behavior in 6 female and 6 male mice of IVCS strain, 20 to 30 weeks old, was studied over a period of 24 days. Weight and style of the nest were used as measures to assess the effects of pup exposure on nest-building. Data were collected between $13: 00$ and 14:00 of each day. Female mice with pup exposure showed significant increases in the nest weight and the percentage of good-excellent nest, while males did not respond.
\end{abstract}

\section{処女マウスの造巣行動に対する新生仔暴露の効果について}

\author{
斎藤 徹 - 勝山慎・高橋和明* \\ 残留農薬研究所毒性部 \\ *日本獣医畜産大学実験動物学研究室
}

マウスの造巣行動は 3 つの要因によって調節されてい る。すなわち, 一定レベルの造巣は生殖に関係なく行わ れるが，妊娠中は progesteroneによってそれが活発化 し, 出産後は仔の存在によって維持されている[2]。

本報では処女マウスの造巣行動に対する新生仔暴露の 効果について検討した。

供試動物は当研究所動物施設で自家繁殖している20 30週齢の IVCS 系処女・雌雄マウス（体重：雌 28.0 30.4 , 雄 36.5 41.2g）であり, 各々 6 匹使用した。飼 育環境条件は温度 $24 \pm 1^{\circ} \mathrm{C}$, 湿度 $55 \pm 5 \%$, 換気回数才 一ル・フレッシュ・エア方式12回/時, 照明14時間/日（朝 5 時点燈, 夜 7 時消燈), 照度 $100 \sim 3001 \mathrm{x}$ (ケージ内： $75 \mathrm{~lx}$ 以上)であった。ケージは金網床アルミ製 $(210 \mathrm{~W}$ $\times 330 \mathrm{D} \times 180 \mathrm{H} \mathrm{mm})$ を用い，それに木毛（後述）を入 れた。自由摄食（固型飼料：CA-1，日本クレア製）お
よび自由拱水の状態で飼育した。

造巣行動の観察には, Lisk et al.の装置[3]を用い, 造巣に使用寸る木毛（材質：松, 規格：1.20 1. $65 \mathrm{~W} \times$ $0.15 \sim 0.30 \mathrm{~T} \times 200 \sim 300 \mathrm{Lmm}$, トキワ科学製）の重量と その巣の形状 $[1]$ について個体別に毎日, 午後 $1 \sim 2$ 時 に記録した。観察期間は雌雄とも24日間であり，その内 訳は次のごとくであった。最初の 8 日間は新生仔を与え ず, 巣を毎日, ケージごと取除いて, 代りに造巣の材料 (50〜60g) をケージとともに与えた。次の 8 日間は木毛 と同時に 1 日齢のIVCS系マウス（原則として雄）1匹 を与えた。最後の 8 日間は再び新生仔を与えず，木毛の みを与えた。これらの手続きに要する時間は 1 個体につ き1分以内であった。雌マウスについてはこの観察期間 中, 毎日，胵垢を採取した。

Fig. 1 に処女・雌雄マウスが造巣に使用した木毛の 


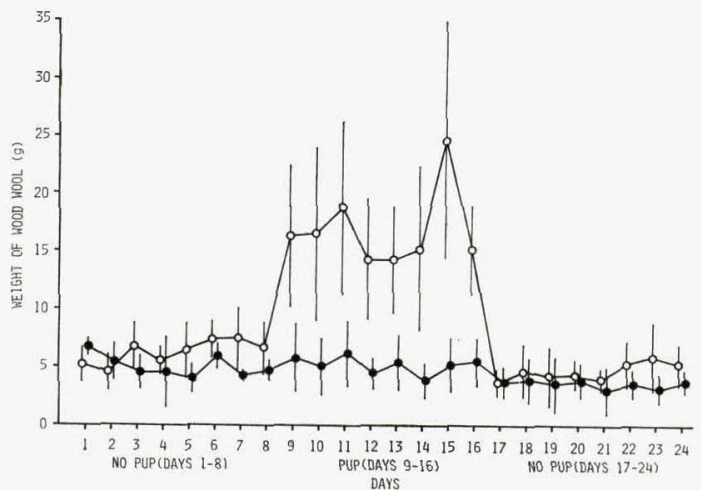

Fig. 1 The average amount of wood wool pulled per day for nest-building by virgin female $(\mathrm{O}-\mathrm{O})$ and male (-) mice with and without pup exposure. Values are mean $\pm \mathrm{SD}$.

重量を示した。

雌マウスでは，新生仔を与えた 8 日間（観察 9 〜 16 日 目）の1日の平均木毛重量は $14.3 \sim 24.6 \mathrm{~g}$ であり, 新 生仔を与えなかった観察 1 ～8 日目までの值 (4.4〜7.5 g) の $2 \sim 6$ 倍量であった $(\mathrm{t}=9.06, \mathrm{p}<0.001)$ 。再 び，観察17〜24日目まで新生仔を与えなかった期間の木 毛の重量は 3.8〜 5.9g であり, 新生仔を与えた期間の 值の $1 / 6 \sim 1 / 2$ 量であった（ $\mathrm{t}=10.53, \mathrm{p}<0.001)$ 。新 生仔を与えなかった前期（観察 1 ～8 日目）と後期（17 〜24日目）の木毛の重量は後期が前期に比べ低值を示し た $(\mathrm{t}=3.74, \mathrm{p}<0.001)$ 。これは新生仔暴露によって 生じた活動六進に対する反動と思われる。

これに対し, 雄マウスでは新生仔を与えても木毛の重 量の増加傾向は認められず，観察期間中の 1 日の平均木 毛重量は $3.1 \sim 6.7 \mathrm{~g}$ であった。

Fig. 2〜4 には造られた巣の形状を図示した。すな わち，雌マウスでは，全例とも新生仔を与えない場合， 平面的な巣 (Fig. 2) であったが，新生仔を与えた場合 には立体的な巣 (Fig. 3) となり, 哺育中のマウスが造 る巣と類似していた。雄マウスでは全例とも新生仔を与 えても，与えない場合と同様，平面的な巣 (Fig. 4) で あった。

なお，木毛の重量および巣の形状と膣垢像との関連は 認められなかった。

最後に, 新生仔を与えた時の母性行動についてみる と, 雌マウスの場合, 新生仔を与えると直ちに, puplicking, nest-building, retrieving の行動がみられ, Noirot [4]抗よ゙斎藤・高橋[5.6]の所見と一致した。
これに対し，雄マウスの場合，6 例中 2 例が実験 期間 中，与えた新生仔すべてを食殺した。

以上のごとく，処女・雌マウスでは雄マウスと異な り，導入された新生仔によって造巣行動の六進が認めら れた。

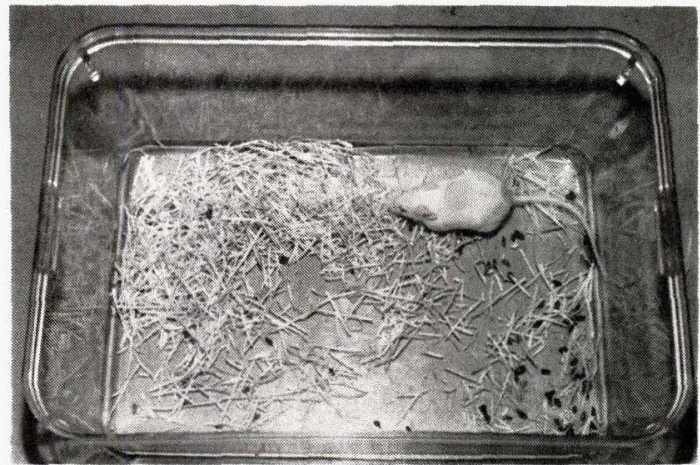

Fig. 2 A poor-fair nest of virgin female and male mice without pup exposure.

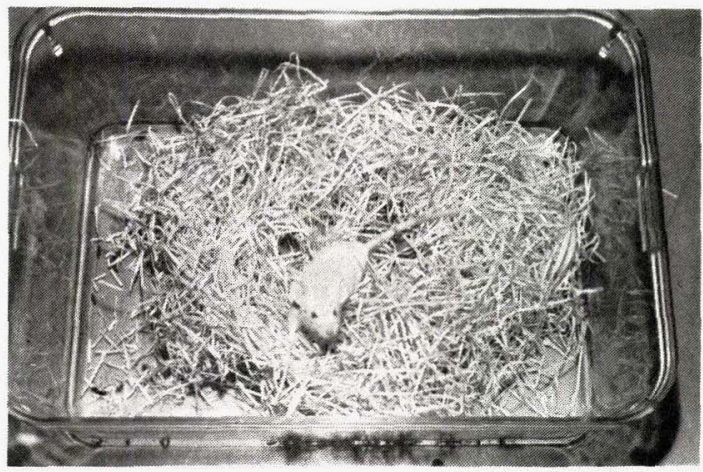

Fig. 3 A good-excellent nest of a virgin female mouse with pup exposure.

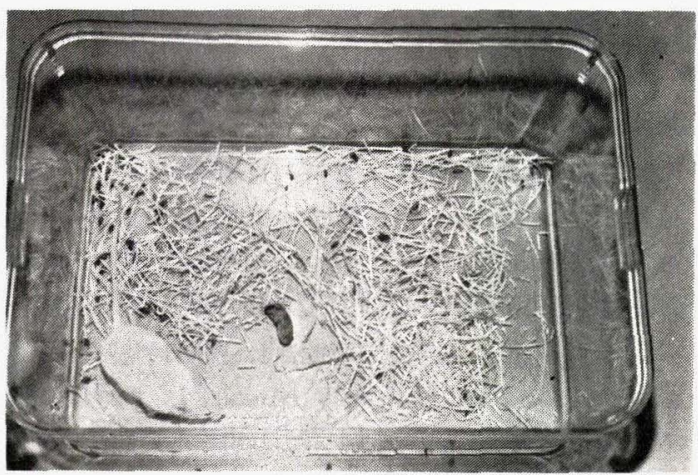

Fig. 4 A poor-fair nest of a virgin male mouse with pup exposure. 
要 約

20〜30週齢の処女・雌雄・IVCS 系マウスの造巣行動 に対する新生仔暴露の効果について, 造巣に使用された 木毛の重量および巣の形状の両面から検討した。木毛は 常時, マウスが採取できる条件下に設置された。観察期 間は24日間であり, 前・後期の各 8 日間は新生仔を与え ず，中期の 8 日間に 1 日齢の新生仔を 1 匹与えた。その 結果, 新生仔暴露により, 雃マウスの巣には量的および 質的効果が現われ哺育中のマウスが造る巣との類似性が 認められた。これに対し, 雄マウスではその効果は認め られなかった。
終わりに臨み, 本実験に対し終始ご助言を賜わった残留農薬 研究所毒性部長白須泰彦博士に深謝する.

\section{文献}

[1] Bridges, R. S., Goldman, B. D., and Bryant, L. P. (1974). Horm. Behav., 5, 219-226.

[2] Koller, G. (1955). Zool. Anz. (suppl.), 19, 123-132.

[3] Lisk, R. D., Pretlow, R. D., and Friedman, S. M. (1969). Anim. Behav., 17, 730-737.

[4] Noirot, E. (1969). Anim. Behav., 17, 547-550.

[5] 斎藤 徹 ・高橋和明 (1979). 家畜繁殖誌. 25, 73-78.

[6] 斎藤 徹・高橋和明 (1979). 家畜繁殖誌. 25, 117-119. 